\title{
Behavior of Soil Chemical Attributes in Field-Forest Succession in Southern Amazonas
}

\author{
Maria Clécia Gomes Sales \\ Instituto de Educação, Agricultura e Ambiente, Universidade Federal do Amazonas, Rua \\ Circular Municipal 1805 São Pedro, Humaitá, Amazonas, Brasil \\ Tel: +5597981129962Ｅ-mail: clecia_sales@hotmail.com
}

Elilson Gomes de Brito Filho

Instituto de Educação, Agricultura e Ambiente, Universidade Federal do Amazonas, Rua Circular Municipal 1805 São Pedro, Humaitá, Amazonas, Brasil

Tel: +5597981106082Ｅ-mail: bfsambiente@gmail.com

\section{Milton César Costa Campos}

Instituto de Educação, Agricultura e Ambiente, Universidade Federal do Amazonas, Rua Circular Municipal 1805 São Pedro, Humaitá, Amazonas, Brasil

Tel: +5597981144618Ｅ-mail: mcesarsolos@gmail.com

\section{José Maurício da Cunha}

Instituto de Educação, Agricultura e Ambiente, Universidade Federal do Amazonas, Rua Circular Municipal 1805 São Pedro, Humaitá, Amazonas, Brasil

Tel: +5597981183520Ｅ-mail: maujmc@gmail.com

\section{Guilherme Abadia Silva}

Instituto de Educação, Agricultura e Ambiente, Universidade Federal do Amazonas, Rua Circular Municipal 1805 São Pedro, Humaitá, Amazonas, Brasil

$$
\text { Tel: +5597984009043Ｅ-mail: gui.abadia.s@gmail.com }
$$




\title{
Macrothink

Instituto de Educação, Agricultura e Ambiente, Universidade Federal do Amazonas, Rua Circular Municipal 1805 São Pedro, Humaitá, Amazonas, Brasil

Tel: +5597984056251Ｅ-mail: elyeng.7@gmail.com

Douglas Marcelo Pinheiro da Silva

Instituto de Educação, Agricultura e Ambiente, Universidade Federal do Amazonas, Rua Circular Municipal 1805 São Pedro, Humaitá, Amazonas, Brasil

Tel: +5597984138017 E-mail: dougllasmarcelo@gmail.com

\section{Flávio Pereira de Oliveira}

Departamento de Solos e Engenharia Rural, Universidade Federal da Paraíba, Rodovia BR 079 - Km 12, Areia, Paraíba, Brasil

Tel: +558333621700 E-mail: pereira@cca.ufpb.br

Fernando Gomes de Souza

Departamento de Agronomia, Universidade Federal de Roraima, Rodovia BR 174, Km 37, Boa Vista, Roraima, Brasil

Tel: +5595991567956_E-mail: nando_gs2@hotmail.com

Received: Apr. 15, $2020 \quad$ Accepted: June 4, $2020 \quad$ Published: June 4, 2020

doi:10.5296/jas.v8i3.16846

URL: https://doi.org/10.5296/jas.v8i3.16846

\begin{abstract}
The use of geostatistical methods in the identification of the size and structure of the spatial variability of soil chemical attributes has been a very important tool in the evaluation and behavior of soil attributes. This research aimed to evaluate the spatial variability of chemical attributes in natural field and forest areas, in the Humaitá region (AM). In these areas, meshes with dimensions of $70 \mathrm{~m} \times 70 \mathrm{~m}$ were established at regular intervals of 10 minutes in the 0.0-0.2 m layers, totaling 64 samples per layer. It was determined: soil $\mathrm{pH}$, phosphorus $(\mathrm{P})$, potassium $\left(\mathrm{K}^{+}\right)$, calcium $\left(\mathrm{Ca}^{2+}\right)$, magnesium $\left(\mathrm{Mg}^{2+}\right)$, aluminum $\left(\mathrm{Al}^{3+}\right)$ and potential acidity $\left(\mathrm{H}^{+}+\mathrm{Al}^{3+}\right)$. Base saturation $(\mathrm{V} \%)$ and sum of bases $(\mathrm{SB})$ were calculated. The data were evaluated by descriptive statistics and spatial dependence analysis, based on the best models and semivariograms adjustment. The chemical attributes are spatially dependent, they present random distribution of ideal sample spacing, considering that the variables that showed
\end{abstract}


dependence were adjusted to the exponential and spherical model. Geostatistic was presented as an appropriate tool, providing information that allows the understanding of the spatial distribution. The degree of dependence was strong and moderate. The highest reaches were recorded in the natural field area.

Keywords: Amazon soils, soil chemistry, geostatistical

\section{Introduction}

Something important about the Amazonian biome highlighted by Melo et al (2017) is the question of biodiversity where the fauna, flora and other resources available its ecosystem, including the soil, are involved. Among the characteristics of the soil of this region included soils with high degree of weathered, with predominance of the classes of Oxisols. Chemically they have high aluminum $\left(\mathrm{Al}^{3+}\right)$ content, but not in toxic quantities for plants, as well as high acidity, low capacity cation exchange (CCE), and these factors influence directly to their low fertility (Campos et al, 2004).

Soil attributes are important components of the productivity since plants need well-structured soils, reason why the selection and proper use of each type of soil are of fundamental importance for maintaining the quality and productivity of the system (Hossain et al., 2016; Faucon et al., 2017). Therefore, to know the soil's structural chemical variability of its attributes becomes a useful tool to understand the variability of its productivity in the area (Braz et al., 2018).

Regarding geostatistics, the study of the spatial variability of soil attributes emerges as an alternative for these purposes, since it allows quantifying the magnitude and degree of spatial dependence, describing in detail, the spatial variability of the variables studied, by means of an interpolator accuracy and precision (Uchôa et al., 2011; Santi et al. , 2012), allowing to indicate alternatives of use, besides a better understanding of the variability of the attributes and their influence on the environment (Silva-Neto et al., 2012 ). The use of geostatistics implies the definition of a sampling plan, defining the number and spacing of the sampling points to be collected. In the literature, this definition varies widely, according to Bottega et al. (2013), Dalchiavon et al. (2016), Araújo et al. (2017) and Carvalho et al. (2018).

In general, geostatistics is a tool used to detect the variability in the environment, allowing the analysis of its characteristics, their random and spatial aspects, creating an image of the variability of characters, identifying the degree of spatial dependence and providing information to support the study of the phenomenon to be analyzed (Siqueira et al., 2015, Lima et al., 2013). The objective of this research was to verify, through the geostatistical tool, the spatial distribution, and its dependence of the soil chemical attributes in natural field area and forest of the Amazon southern region.

\section{Material and Methods}

The study was carried out in an experimental area located south of the State of Amazonas, under the geographical coordinates of $7^{\circ} 30^{\prime} 24^{\prime}$ 'S and 63 $04^{\prime} 56^{\prime \prime} \mathrm{W}$ (natural field area) and $7^{\circ} 30^{\prime} 24^{\prime} \mathrm{S}$ and $63^{\circ} 04^{\prime} 56^{\prime} \mathrm{W}$, in the area of the 54th Jungle Infantry Battalion of the 
Brazilian Army. The climatic zone of the region, according to the classification of Köppen belongs to group A (Tropical Rainy Weather) and climatic type Am (rainfall of the monsoon type), presenting a dry period of small duration, with annual average rainfall varying between 2,250 and 2,750 $\mathrm{mm}$ and with rainy season beginning in October and continuing until June (Brazil, 1978).

Soil samples were collected in the natural field and forest areas, with sample mesh scheme established in each environment, with dimensions of $70 \times 70 \mathrm{~m}$ and regular spacing between sampling points of $10 \mathrm{~m}$, at a depth of $0.20 \mathrm{~m}$, totaling 64 samples. Each sampling point was georeferenced, for the construction of the digital elevation model (DEM).

In relation to the chemical analyzes, the $\mathrm{pH}$ was determined potentiometrically using water and soil ratio in 1:2.5 (EMBRAPA, 2017). The potential acidity ( $\mathrm{H}+\mathrm{Al})$ was determined from the extraction using calcium acetate solution buffered to $\mathrm{pH}$ 7.0. Based on this data, were calculated sum of bases (SB), cation exchange capacity (CEC), base saturation (V\%) and aluminum saturation (m\%) (EMBRAPA, 2017).

Total carbon was determined by the method of Walkley Black, modified by Yeomans \& Bremner (1988). The organic matter was estimated from the values of organic carbon. Calcium $(\mathrm{Ca})$, exchangeable aluminum ( $\mathrm{Al}$ ) were determined by extraction using $\mathrm{KCl}$ at 1 mol. $\mathrm{L}^{-1}$, Potassium (K) and Phosphorus (P) available, were extracted with a solution of Mehlich $^{-1}$ (EMBRAPA, 2017). The results were submitted for descriptive statistical analysis, obtaining mean, median, minimum, maximum, standard deviation coefficients of asymmetry and kurtosis and coefficient of variation $(\mathrm{CV})$, to the adhesion test of Kolmogorov Smirnov, at the $5 \%$ level of significance.

Geostatistics has been used to assess the spatial variability of soil chemical attributes based on the determination coefficient $\left(\mathrm{R}^{2}\right)$ and cross-validation, which, as ideal provides linear coefficient equal to zero; slope coefficient equal to one; and equal validation coefficient of cross validation $\left(\mathrm{R}^{2}{ }_{\mathrm{vc}}\right.$ ) equal (Vieira, 2000). In order to carry out the geostatistical analysis, it was necessary to know if there was spatial dependence or not of these attributes studied, which can be verified by semivariogram graphs. The semivariogram is a graphical representation of the semivariance $\mathrm{y}(\mathrm{h})$, represented in the $\mathrm{Y}$ coordinate, as a function of a given distance $(h)$, represented in the $\mathrm{X}$ coordinate. The semivariogram can be estimated by the following equation (1):

$$
\hat{\gamma}(h)=\frac{1}{2 N(h)} \sum_{i=1}^{N(h)}\left[Z\left(x_{i}\right)-Z\left(x_{i}+h\right)\right]^{2}
$$

Where: $N(h)$ represents the number of pairs of measured values, $Z(x i)$ and $Z(x i+h)$, separated by a given distance $(h)$. The values of $Z$ can be any of the parameters studied, while the values of $x i$ and $x i+h$ are defined according to the positions of the sample points in the field.

After calculating the semivariograms, the semivariance values $y(h)$ and distance $(h)$ are arranged in scatter plots, with $\mathrm{Y}$ values as the semivariances, and $\mathrm{X}$ the distances. The 
adjustment of theoretical models with experimental semivariograms was determined, using the GS + software (Robertson, 1998), the nugget coefficients $\left(C_{0}\right)$, the level $\left(C_{0}+C_{1}\right)$, the structural variance $\left(\mathrm{C}_{1}\right)$ and range (a). This software applies the method of least squares and adopts as criteria by selecting the highest value of $\mathrm{R}^{2}$ (coefficient of determination) and by the highest value of the correlation coefficient obtained by the cross-validation method.

Semivariograms of spherical and exponential types were tested. When there was spatial dependence, that is, when the function y $(\mathrm{h})$ was distance $(\mathrm{h})$ dependent, the neighboring values were similar, making it possible to estimate values for locations where the attributes were not measured.

For the analysis of the degree of spatial dependence (DSD), the $\mathrm{C}_{0} /\left(\mathrm{C}_{0}+\mathrm{C}_{1}\right)$ ratio was used and the intervals proposed by Cambardela et al. (1994) considering weak spatial dependence (DSD $>75 \%)$, moderate $(25 \% \leq \mathrm{DSD} \leq 75 \%)$ and strong (DSD $<25 \%)$. After confirming that there was spatial dependence, the ordinary kriging interpolation method was used to estimate values at unmeasured locations (VIEIRA, 2000).

\section{Results and Discussion}

According to Braun \& Ramos (1959), the region presents an approximate relief to the "board" type, with very small gradients and slightly bulging edges and geology formed by undifferentiated ancient alluvium, referred to the Holocene. Considering that the most common environments present in the southern Amazon are of natural field and forest, two contiguous areas were chosen, with the presence of a natural field and forest, in which the soils are classified as Cambissolo Háplico and Argissolo Vermelho (Campos et al., 2012).

The results of the descriptive statistics for chemical attributes of studied soils in forest area and natural field are shown in Table 1 . The mean and median values for all variables showed similarity, tending to a symmetrical data distribution. According to Lima et al. (2014), values close to average and median, meet the normality conditions, that is, the values are not dominated by atypical values of distribution and are more suitable for use of geostatistics. The coefficients of asymmetry and kurtosis close to zero reinforce the proximity to symmetry in the data distribution. Cortez et al. (2011) point out that asymmetry and kurtosis confirm as indicators of distribution of the analyzed values, in which the ideal is that they are close to zero.

It is possible to observe that these soils are acidic, which is common considering the nature of Amazonian soils, in this case the sandstone, and the volume of organic material that is deposited and when it enters a state of decomposition releases humic fractions, which increase soil acidity (humic acid, humic acid and flavic acid) (Moline et al., 2015, Santos, et al., 2019). 
Table 1. Descriptive analysis of soil chemical attributes in forest area and natural field in the southern region of Amazonas

\begin{tabular}{|c|c|c|c|c|c|c|c|c|c|}
\hline Attributes & M & Med & $\sigma$ & $\mathrm{CV}$ & Curt & Ass & $\mathrm{Mx}$ & $\mathrm{Mn}$ & $\mathrm{d}$ \\
\hline \multicolumn{10}{|c|}{ Forest } \\
\hline $\mathrm{pH}$ in water & 4.30 & 4.30 & 0.08 & 1.86 & -0.53 & -0.08 & 4.47 & 4.15 & $0.20 *$ \\
\hline $\mathrm{P}\left(\mathrm{mg} \mathrm{dm}^{-3}\right)$ & 0.64 & 0.65 & 0.46 & 71.85 & -0.35 & 0.49 & 0.93 & 0.46 & $0.20^{*}$ \\
\hline $\mathrm{K}^{+}\left(\mathrm{cmol}_{\mathrm{c}} \cdot \mathrm{dm}^{-3}\right)$ & 0.09 & 0.09 & 0.01 & 11.11 & -0.57 & 0.32 & 0.13 & 0.06 & 0.00 \\
\hline $\mathrm{Ca}^{2+}\left(\mathrm{cmol}_{\mathrm{c} . \mathrm{dm}^{-3}}\right)$ & 1.07 & 1.04 & 0.07 & 6.54 & -0.29 & 0.65 & 1.25 & 0.95 & 0.00 \\
\hline $\mathrm{Mg}^{2+}\left(\mathrm{cmol}_{\mathrm{c}} \cdot \mathrm{dm}^{-3}\right)$ & 0.27 & 0.27 & 0.02 & 7.40 & 0.01 & 0.64 & 0.35 & 0.23 & 0.00 \\
\hline $\mathrm{Al}^{3+}\left(\mathrm{cmol}_{\mathrm{c} .} \mathrm{dm}^{-3}\right)$ & 4.18 & 4.20 & 0.50 & 11.96 & 0.13 & 0.11 & 5.40 & 3.00 & $0.20 *$ \\
\hline $\mathrm{H}^{+} \mathrm{Al}^{3+}\left(\mathrm{cmol}_{\mathrm{c} .} \mathrm{dm}^{-3}\right)$ & 7.11 & 7.26 & 1.01 & 14.20 & 6.44 & -1.12 & 9.41 & 2.48 & 0.04 \\
\hline $\mathrm{SB}\left(\mathrm{cmol}_{\mathrm{c} .} \mathrm{dm}^{-3}\right)$ & 1.47 & 1.45 & 0.10 & 6.80 & -0.88 & 0.40 & 1.70 & 1.29 & 0.04 \\
\hline $\mathrm{CEC}\left(\mathrm{cmol}_{\mathrm{c}} \cdot \mathrm{dm}^{-3}\right)$ & 8.76 & 8.76 & 0.77 & 8.78 & 0.41 & 0.75 & 10.80 & 7.63 & $0.20 *$ \\
\hline $\mathrm{V}(\%)$ & 16.94 & 17.10 & 1.77 & 10.44 & -0.28 & -0.37 & 20.64 & 12.89 & $0.20 *$ \\
\hline $\mathrm{m}(\%)$ & 74.13 & 74.07 & 3.20 & 4.31 & -0.44 & 0.04 & 81.16 & 67.49 & $0.20 *$ \\
\hline $\mathrm{OC}\left(\mathrm{mg} \mathrm{kg}^{-3}\right)$ & 27.69 & 27.36 & 2.39 & 8.63 & -0.99 & 0.21 & 31.99 & 23.24 & $0.20 *$ \\
\hline $\mathrm{OM}\left(\mathrm{mg} \mathrm{kg}^{-3}\right)$ & 45.61 & 45.71 & 1.74 & 3.81 & -0.05 & -0.06 & 49.25 & 41.98 & $0.20 *$ \\
\hline \multicolumn{10}{|c|}{ Natural Field } \\
\hline $\mathrm{pH}$ in water & 5.12 & 5.12 & 0.18 & 3.51 & -0.73 & 0.34 & 5.46 & 4.68 & $0.05^{*}$ \\
\hline $\mathrm{P}\left(\mathrm{mg} \mathrm{dm}^{-3}\right)$ & 0.44 & 0.44 & 0.05 & 11.36 & -0.58 & 0.10 & 0.56 & 0.34 & $0.20 *$ \\
\hline $\mathrm{K}^{+}\left(\mathrm{cmol}_{\mathrm{c}} \cdot \mathrm{dm}^{-3}\right)$ & 0.06 & 0.06 & 0.04 & 66.66 & -0.45 & 0.46 & 0.08 & 0.05 & 0.00 \\
\hline $\mathrm{Ca}^{2+}\left(\mathrm{cmol}_{\mathrm{c}} \cdot \mathrm{dm}^{-3}\right)$ & 1.15 & 1.16 & 0.07 & 6.08 & -0.62 & 0.24 & 1.33 & 1.03 & $0.20^{*}$ \\
\hline $\mathrm{Mg}^{2+}\left(\mathrm{cmol}_{\mathrm{c}} \cdot \mathrm{dm}^{-3}\right)$ & 0.37 & 0.35 & 0.04 & 10.81 & -0.56 & 0.66 & 0.48 & 0.31 & 0.00 \\
\hline $\mathrm{Al}^{3+}\left(\mathrm{cmol}_{\mathrm{c}} \cdot \mathrm{dm}^{-3}\right)$ & 1.38 & 1.35 & 0.31 & 22.46 & 0.39 & 0.90 & 2.30 & 1.00 & 0.00 \\
\hline $\mathrm{H}^{+} \mathrm{Al}^{3+}\left(\mathrm{cmol}_{\mathrm{c} . \mathrm{dm}^{-3}}\right)$ & 5.53 & 5.45 & 1.15 & 20.79 & -0.24 & 0.54 & 8.42 & 3.80 & $0.18^{*}$ \\
\hline $\mathrm{SB}\left(\mathrm{cmol}_{\mathrm{c} .} \mathrm{dm}^{-3}\right)$ & 1.59 & 1.60 & 0.08 & 5.03 & -0.61 & 0.10 & 1.81 & 1.43 & $0.20 *$ \\
\hline CEC ( cmolc. $\left.\mathrm{dm}^{-3}\right)$ & 7.11 & 7.10 & 1.08 & 15.18 & -0.73 & 0.18 & 19.38 & 5.26 & $0.20 *$ \\
\hline $\mathrm{V}(\%)$ & 22.95 & 22.74 & 3.48 & 15.16 & -0.80 & 0.16 & 29.94 & 16.30 & $0.20 *$ \\
\hline $\mathrm{m}(\%)$ & 46.52 & 46.00 & 6.18 & 13.28 & -0.07 & 0.65 & 61.36 & 36.46 & $0.20^{*}$ \\
\hline $\mathrm{OC}\left(\mathrm{mg} \mathrm{kg}^{-3}\right)$ & 26.50 & 26.40 & 1.54 & 5.81 & -0.68 & -0.10 & 29.71 & 23.48 & $0.20^{*}$ \\
\hline $\mathrm{OM}\left(\mathrm{mg} \mathrm{kg}^{-3}\right)$ & 45.69 & 45.52 & 2.66 & 5.82 & -0.10 & -0.68 & 51.22 & 40.48 & $0.20 *$ \\
\hline
\end{tabular}


$\mathrm{M}=$ average; Med=median; $\sigma=$ Standard deviation, $\mathrm{CV}=$ Coefficient of variation, Curt = Kurtosis coefficient, Ass = Asymmetry coefficient, $\mathrm{Mx}=$ Maximum, $\mathrm{Mn}=$ Minimum and $\mathrm{d}=$ Kolmogorov-Smirnov; *significant at $5 \%$ probability.

It is also possible to observe that the forest area has potentially higher levels of potential acidity and exchangeable aluminum which would disfavor vegetation growth, since these compete with the same sites of absorption as essential elements for the plants (Carneiro et al. , 2018), but when looking at the values of CEC and OC, and considering that these are closely related in the soil, it is possible to verify why the forest soils still stand out with respect to amounts of vegetation, which are directly related to cycling of nutrients (Souza et al., 2019).

Another factor that can be associated with the contribution of vegetation is with regard to nutrient values. In the natural field area it is possible to observe a typical vegetation of the cerrado, low vegetation with predominance of trees and shrubs, which are associated with the presence of nutrients in the unavailable form, since the absorption sites are filled with $\mathrm{H}^{+}$and $\mathrm{Al}^{3+}$ ions, affecting both the performance of the vegetation considering that they are resistant plants, limiting the tree size to low size species, thus causing even near areas and natural areas such as forest area and natural field to be similar (Mascarenhas et al., 2017).

As for organic carbon and organic matter, it is possible to verify that the values were higher in the natural field area than in the forest as expected, the forest has a high organic material input, but its carbon is stored in the vegetation, different of the natural field area that is found in the soil, stored and released more easily as $\mathrm{CO}_{2}$ (Santos et al., 2019).

Regarding the normality of the data submitted to the Kolmogorov-Smirnov test (Table 1), it was verified that most variables were significant at the $5 \%$ probability level, except in the forest area for attributes $\mathrm{K}^{+}, \mathrm{Ca}^{2+}, \mathrm{Mg}^{2+}, \mathrm{Al}^{3+}, \mathrm{H}^{+}+\mathrm{Al}^{3+}$ and in the natural field area for $\mathrm{K}^{+}$, $\mathrm{Mg}^{2+}$, and $\mathrm{Al}^{3+}$. The normality of the data is not a requirement for geostatistics, and it is only appropriate that the distribution does not present very elongated tails, thus compromising the analyzes (CRESSIE, 1991).

Adopting the criteria proposed by Warrick; Nielsen (1980), who consider the values of coefficient of variation between $12 \%$ and $60 \%$ as an average variability, values below $12 \%$, as low variability and above $60 \%$, high variability, it can be stated based on the results found that the attributes of the forest area and natural field both presented low variability for $\mathrm{pH}, \mathrm{K}^{+}$, $\mathrm{Ca}^{2+}, \mathrm{Mg}^{2+}, \mathrm{Al}^{3+}, \mathrm{SB}, \mathrm{CEC}, \mathrm{V} \%, \mathrm{~m} \%$ and $\mathrm{OC}$, with the exception of $\mathrm{H}^{+}+\mathrm{Al}^{3+}$ that presented moderate variability and $\mathrm{P}$ available, which presented high variability for forest area and low variability for natural field.

According to Nogueira (2007) a coefficient of variation higher than $35 \%$ reveals that the series is heterogeneous and the mean has little importance; if it is higher than $65 \%$, the series is very heterogeneous and the mean has no meaning, but if it is less than $35 \%$ the series it is homogeneous and the mean has significance which can be used as representative of the series from which it was obtained. In this way, it can be said that $\mathrm{pH}$ in water, $\mathrm{Ca}^{2+}, \mathrm{Mg}^{2+}, \mathrm{OC}$ and OM presented a homogeneous data series, thus characterizing their averages as significant, the exception was observed for the variable $\mathrm{P}$ available in the forest area, which presented a 


\section{Macrothink}

series of heterogeneous data (Table 1).

Table 2 shows the results of the nugget effect, level, reach, semivariograms models fitted to the experimental data, as well as the nugget/landing ratio with spatial dependence of soil chemical attributes. Based on the geostatistical analysis using semivariograms, it was possible to observe that all the chemical attributes studied presented spatial dependence. Given to this fact, it is possible to verify that this is a clear indication that these attributes are spatially dependent, present a random distribution of ideal sample spacing, when considering that the variables that showed dependence were adjusted to the exponential and spherical model. Thus, a high correction between the attributes in the studied space can be assumed (SOARES et al., 2018).

The degree of spatial dependence (DSD), expressed by the ratio between the nugget effect and the level, followed the classification of Cambardella et al. (1994). In the forest area, the variables $\mathrm{pH}$ in water, $\mathrm{P}$ available, $\mathrm{H}^{+}+\mathrm{Al}^{3+}, \mathrm{SB}, \mathrm{V} \%$ in, were classified as moderate in referred depth, except the variables $\mathrm{K}^{+}, \mathrm{Ca}^{2+}, \mathrm{Mg}^{2+}, \mathrm{Al}^{3+}, \mathrm{CEC}, \mathrm{OC}$ and $\mathrm{OM}$, which were classified with strong DSD (Table 2). Similar behavior was found in the natural field, where strong DSD was predominant, with an exception only of $\mathrm{pH}$ in water, $\mathrm{K}^{+}, \mathrm{H}^{+}+\mathrm{Al}^{3+}, \mathrm{V} \%, \mathrm{CO}$ and OM, classified with moderate DSD (Table 2).

According to Cambardella et al. (1994) the variables that exhibit strong spatial dependence are influenced by the intrinsic properties of the soil and its formation factors, while the moderate spatial dependence being influenced by the homogenization of the soil, while the extrinsic ones were attributed with weak dependence. In a way a strong spatial dependence indicates little management action needed, so whenever there is a change every environment will feel the impact, since they are strongly correlated. 
Table 2. Geostatistical parameters of soil chemical attributes in forest area and natural field in the southern region of Amazonas

\begin{tabular}{|c|c|c|c|c|c|c|c|}
\hline Attributes & Model & Nugget effect & Level & Reach & ${ }^{2} \mathrm{R}^{2}$ & ${ }^{5} \mathrm{CV}$ & ${ }^{1} \mathrm{DSD}$ \\
\hline \multicolumn{8}{|c|}{ Forest } \\
\hline $\mathrm{pH}$ in water & ${ }^{3} \mathrm{Exp}$. & 0.004 & 0.01 & 12.20 & 0.85 & 0.860 & 35.96 \\
\hline $\mathrm{P}\left(\mathrm{mg} \mathrm{dm}^{-3}\right)$ & ${ }^{4}$ Esf. & 0.010 & 0.02 & 28.80 & 0.92 & 0.890 & 49.76 \\
\hline $\mathrm{K}^{+}\left(\mathrm{cmol}_{\mathrm{c} \cdot} \cdot \mathrm{dm}^{-3}\right)$ & Exp. & 0.004 & 0.08 & 40.76 & 0.92 & 0.778 & 5.26 \\
\hline $\mathrm{Ca}^{2+}\left(\mathrm{cmol}_{\mathrm{c} . \mathrm{dm}^{-3}}\right)$ & Exp. & 0.004 & 0.06 & 26.30 & 0.92 & 0.784 & 0.15 \\
\hline $\mathrm{Mg}^{2+}\left(\mathrm{cmol}_{\mathrm{c}} \cdot \mathrm{dm}^{-3}\right)$ & Exp. & 0.001 & 0.01 & 21.95 & 0.95 & 0.752 & 0.76 \\
\hline $\mathrm{Al}^{3+}\left(\mathrm{cmol}_{\mathrm{c} .} \mathrm{dm}^{-3}\right)$ & Exp. & 0.015 & 0.22 & 74.30 & 0.96 & 0.897 & 7.25 \\
\hline $\mathrm{H}^{+} \mathrm{Al}^{3+}\left(\mathrm{cmol}_{\mathrm{c}} \cdot \mathrm{dm}^{-3}\right)$ & Exp. & 0.556 & 1.47 & 29.90 & 0.92 & 0.833 & 37.92 \\
\hline $\mathrm{SB}\left(\mathrm{cmol}_{\mathrm{c} .} \cdot \mathrm{dm}^{-3}\right)$ & Exp. & 0.581 & 1.65 & 82.30 & 0.86 & 0.877 & 35.12 \\
\hline $\mathrm{CEC}\left(\mathrm{cmol}_{\mathrm{c} \cdot} \cdot \mathrm{dm}^{-3}\right)$ & Exp. & 1.718 & 11.64 & 15.70 & 0.79 & 0.919 & 14.76 \\
\hline $\mathrm{V}(\%)$ & Exp. & 0.038 & 0.11 & 44.56 & 0.92 & 0.925 & 35.84 \\
\hline $\mathrm{m}(\%)$ & Exp. & 2.102 & 6.57 & 12.00 & 0.87 & 0.871 & 31.98 \\
\hline $\mathrm{OC}\left(\mathrm{mg} \mathrm{kg}^{-3}\right)$ & Exp. & 0.925 & 3.86 & 21.70 & 0.91 & 0.969 & 23.96 \\
\hline $\mathrm{OM}\left(\mathrm{mg} \mathrm{kg}^{-3}\right)$ & Exp. & 0.680 & 5.13 & 43.50 & 0.84 & 0.932 & 13.25 \\
\hline \multicolumn{8}{|c|}{ Natural Field } \\
\hline $\mathrm{pH}$ in water & Exp. & 0.011 & 0.04 & 44.70 & 0.910 & 0.832 & 27.50 \\
\hline $\mathrm{P}\left(\mathrm{mg} \mathrm{dm}^{-3}\right)$ & Exp. & 0.006 & 0.04 & 39.60 & 0.949 & 0.897 & 14.28 \\
\hline $\mathrm{K}^{+}\left(\mathrm{cmol}_{\mathrm{c}} \cdot \mathrm{dm}^{-3}\right)$ & Exp. & 0.005 & 0.01 & 48.00 & 0.838 & 0.880 & 45.45 \\
\hline $\mathrm{Ca}^{2+}\left(\mathrm{cmol}_{\mathrm{c}} \cdot \mathrm{dm}^{-3}\right)$ & Exp. & 0.001 & 0.06 & 26.30 & 0.924 & 0.765 & 0.15 \\
\hline $\mathrm{Mg}^{2+}\left(\mathrm{cmol}_{\mathrm{c}} \cdot \mathrm{dm}^{-3}\right)$ & Exp. & 0.001 & 0.01 & 26.60 & 0.947 & 0.766 & 7.69 \\
\hline $\mathrm{Al}^{3+}\left(\mathrm{cmol}_{\mathrm{c} .} \mathrm{dm}^{-3}\right)$ & Exp. & 0.015 & 0.22 & 74.30 & 0.963 & 0.897 & 7.24 \\
\hline $\mathrm{H}^{+} \mathrm{Al}^{3+}\left(\mathrm{cmol}_{\mathrm{c}} \cdot \mathrm{dm}^{-3}\right)$ & Exp. & 0.532 & 1.15 & 86.70 & 0.906 & 0.807 & 46.26 \\
\hline $\mathrm{SB}\left(\mathrm{cmol}_{\mathrm{c}} \cdot \mathrm{dm}^{-3}\right)$ & Exp. & 2.267 & 13.31 & 15.60 & 0.832 & 0.778 & 17.03 \\
\hline CEC (cmolc. dm $\left.{ }^{-3}\right)$ & Exp. & 5.845 & 0.53 & 22.53 & 0.902 & 0.840 & 1.09 \\
\hline $\mathrm{V}(\%)$ & Exp. & 2.001 & 3.86 & 14.50 & 0.940 & 0.918 & 51.81 \\
\hline $\mathrm{m}(\%)$ & Exp. & 0.459 & 0.19 & 15.905 & 0.856 & 0.945 & 2.42 \\
\hline $\mathrm{OC}\left(\mathrm{mg} \mathrm{kg}^{-3}\right)$ & Exp. & 0.010 & 2.01 & 80.40 & 0.919 & 0.873 & 28.59 \\
\hline $\mathrm{OM}\left(\mathrm{mg} \mathrm{kg}^{-3}\right)$ & Esf. & 1.940 & 6.84 & 10.80 & 0.878 & 0.893 & 28.35 \\
\hline
\end{tabular}


${ }^{1} \mathrm{DSD}$ : degree of spatial dependence; ${ }^{2} \mathrm{R}^{2}$ : coefficient of determination; ${ }^{3}$ Exp: exponential; ${ }^{4}$ Esf: Spherical; ${ }^{5} \mathrm{CV}$ : cross validation.

The semivariograms analysis for the chemical attributes studied did not indicate any preferential direction, that is, the data does not have anisotropy; the spatial variability of the data occurs in the same way in all directions (VIEIRA, 2000).

\section{Conclusion}

Soils studied showed high acidity, dystrophic character, high values of exchangeable aluminum and potential acidity. The chemical attributes are crucial in the differentiation of the environments in terms of vegetation. The spatial distribution, in the forest area and natural field, presented a strong and moderate degree of spatial dependence. The largest results were found in the natural field area, which indicates that there is a greater variability of attributes in this environment.

\section{Acknowledgment}

The authors would like to thank FAPEAM, CNPq and CAPES for their support.

\section{References}

Araújo, G., Ferraz, S., Silva, F. M., Oliveira, M. S., Custódio, P. A. A., \& Ferraz, P. F. P. (2017). Variabilidade espacial dos atributos da planta de uma lavoura cafeeira. Revista Ciência Agronômica, 48(1), 81-91, https://doi.org/10.5935/1806-6690.20170009

Bottega, E. L., Queiroz, D. M., Pinto, F. D. A. C., \& Souza, C. M. A. (2013). Variabilidade espacial de atributos do solo em sistema de semeadura direta com rotação de culturas no cerrado brasileiro. Revista Ciência Agronômica, 44(1), 1-9, https://doi.org/10.1590/S1806-66902013000100001

BRASIL. (1978). Ministério Das Minas E Energia. Projeto Radam Brasil, folha SB., 21, Tapajós. Rio de Janeiro. 561p.

Braun, E. H. G., \& Ramos, J. R. A. (1959). Estudo agroecológico dos campos Puciarí-Humaitá (Estado do Amazonas e Território Federal de Rondônia). Revista Brasileira de Geografia, 21(4), 443-497.

Braz, J. A., Freitas, A. S., Miranda, W. L., Silva, L. C., Lacerda N. H., \& Mendonça, A. T. (2018). Distribuição espacial da severidade da brusone do trigo correlacionada com a fertilidade do solo e produção. Revista da Universidade Vale do Rio Verde, 16(2), 1-8, http://dx.doi.org/10.5892/ruvrd.v16i2.5021

Cambardella, C. A., Moorman, T. B., Parkin, T. B., Karlen, D. L., Novak, J. M., Turco, R. F., \& Konopka A. E. (1994). Variabilidade no campo escala das propriedades do solo em Central Iowa. Soil Science Society of America Journal, 58(5), 1501-1511, https://doi.org/10.2136/sssaj1994.03615995005800050033x

Campos, M. C. C., Ribeiro, M. R., Souza Júnior, V. D., Ribeiro Filho, M. R., \& Almeida, M. C. (2012b). Topossequência de solos na transição campos naturais-floresta na região de 
Humaitá, Amazonas. Acta Amazônia, 387-398, https://doi.org/10.1590/S0044-59672012000300011

Campos, M. C. C., Santos, L. A. C., Silva, D. M. P., Mantovanelli, B. C., \& Soares, M. D. R. (2012a). Caracterização física e química de terras pretas arqueológicas e de solos não antropogênicos na região de Manicoré, Amazonas. Revista Agro@mbiente On-line, 6(2), 102-109. http://dx.doi.org/10.18227/1982-8470ragro.v6i2.682

Carneiro, J. S. S., Sousa, S. A., Nikkel, M., Deusdará, T. T., Machado, Â. F., \& Silva, R. R. (2018). Supercalagem: alterações em atributos químicos de um Latossolo Vermelho amarelo distrófico. Revista de ciências agroambientais 16(1), 31-38.

Carvalho, P. S. M., Silva, S. A., Paiva, A. Q., Sodré, G. A., \& Lima, J. S. S. (2018). Variabilidade espacial da fertilidade de um solo cultivado com cacaueiro. Revista Engenharia na Agricultura, 26(2), 178-189.

Cortez, J. W., Alves, A. D. S., Moura, R. D., Olszevski, N., \& Nagahama, H. J. (2011). Atributos físicos do Argissolo amarelo do semiárido nordestino sob sistemas de preparo. Revista Brasileira de Ciência do Solo, 35(4), 1207-1216, https://doi.org/10.1590/S0100-06832011000400014

Cressie, N. Statistics for spatial data. New York, John Wiley, 900p, 1991.

Dalchiavon, F. C., Rodrigues, A. R., Lima, E. S., Lovera, L. H., \& Montanari, R. (2016). Variabilidade espacial de atributos químicos do solo cultivado com soja sob plantio direto. Revista de Ciências Agroveterinárias, 16(2), 144-154, https://doi.org/10.5965/223811711622017144

Empresa Brasileira de Pesquisa Agropecuária - EMBRAPA. (2017). Manual de métodos de análise de solo. 3. ed. Rio de Janeiro: Embrapa Solo, 230p.

Faucon, M. P., Houben, D., \& Lambers, H. (2017). Plant functional traits: soil and ecosystem

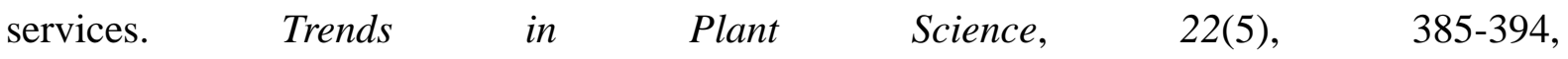
http://doi.org/10.1016/j.tplants.2017.01.005

Hossain, M. S., Hossain, A., Sarkar, M. A. R., Jahiruddin, M., Silva, J. A. T., \& Hossain, M. I. (2016). Productivity and soil fertility of the rice-wheat system in the High Ganges River Floodplain of Bangladesh is influenced by the inclusion of legumes and manure. Agriculture, Ecosystems \& Environment, 218, 40-52, https://doi.org/10.1016/j.agee.2015.11.017

Lima, E. S., Souza, Z. M., Montanari, R., Lovera, L. H., Torres, J. L. R., Esteban, D. A. A., \& Bartieres, E. M. M. (2018). Variabilidade espacial e temporal do solo adubado com resíduos de celulose. Revista Brasileira de Ciências Agrárias (Agrária), 13(4), 1-9, htt://doi.org/10.5039/agraria.v13i4a5598

Lima, G. C., Silva, M. L., Oliveira, S. M., Curi, N., Silva, M. A., \& Oliveira, A. H. (2014). Variabilidade de atributos do solo sob pastagens e mata atlântica na escala de microbacia hidrográfica. Revista Brasileira de Engenharia Agrícola e Ambiental, 18(5), 517-526, https://doi.org/10.1590/S1415-43662014000500008 
Lima, J. S. S., Silva, S. A., \& Silva, J. M. (2013). Variabilidade espacial de atributos químicos de um Latossolo Vermelho-Amarelo cultivado em plantio direto. Revista Ciência Agronômica, 44(1), 16-23, https://doi.org/10.1590/S1806-66902013000100003

Marques, J. D. O., Libardi, P. L., Teixeira, W. G., \& Reis, A. M. (2004). Estudo de parâmetros físicos, químicos e hídricos de um Latossolo Amarelo, na região Amazônica. Acta Amazônica, 34(2), 145-154 https://doi.org/10.1590/S0044-59672004000200002

Mascarenhas, A. R. P., Sccoti, M. S. V., Melo, R. R., Corrêa, F. L. O., Souza, E. F. M., Andrade, R. A., \& Müller, M. W. (2017). Atributos físicos e estoques de carbono do solo sob diferentes usos da terra em Rondônia, Amazônia Sul-Ocidental. Pesquisa florestal Brasileira, 37(89), 19-27 https://doi.org/10.4336/2017.pfb.37.89.1295

Melo, V. F., Orrutéa, A. G., Motta, A. C. V., \& Testoni, S. A. (2017). Land Use and Changes in Soil Morphology and Physical-Chemical Properties in Southern Amazon. Revista Brasileira de Ciência do Solo, 41, 1-14 https://doi.org/10.1590/18069657rbcs20170034

Moline, E. F., \& Coutinho, E. L. M. (2015). Atributos químicos de solos da Amazônia Ocidental após sucessão da mata nativa em áreas de cultivo. Revista de Ciências Agrárias Amazonian Journal of Agricultural and Environmental Sciences, 58(1), 14-20.

Nogueira, M. C. S. (2007). Experimentação agronômica I. Piracicaba: Universidade de São Paulo, 463p

Robertson, G. P. (1998). GS+: Geoestatistics for the environmental sciencies. GS+ User.s Guide. Plainwell, Gamma Desing Software, 152p.

Santi, L. A., Fiorin, J. E., Cocco, K. L. T., Cherubin, M. R., Eitelwein, M. T., Amado, T. J. C., \& Hauschild, F. E. G. (2012). Distribuição horizontal e vertical de fósforo e potássio em área manejada com ferramentas de agricultura de precisão. Revista Plantio Direto, 44, 18-25.

Santos, F. A. S., Pierangeli, M. A. P., Silva, F. L., Serafim, M. E., \& Souza, C. A. (2019). Atributos químicos, físicos e estoque de cálcio, magnésio, potássio e fósforo em solos de campos de murundus no Brasil. Acta Amazonica, 45(1), 101-110, https://doi.org/10.1590/1809-4392201402954

Santos, K. F., Barbosa, F. T., Bertol, I., Werner, R.S., Wolschick, N. H., \& Mota, J. M. (2019). Teores e estoques de carbono orgânico do solo em diferentes usos da terra no Planalto Sul de Santa Catarina. Revista de Ciências Agroveterinárias, 18(2), 222-229, https://doi.org/10.5965/223811711812019222

Silva Neto, S. P., Santos, A. C., Lima Leite, R. L., Dim, V. P., Cruz, R. S., Pedrico, A., \& Neves Neto, D. N. (2011). Análise espacial de parâmetros da fertilidade do solo em região de ecótono sob diferentes usos e manejos. Semina: Ciências Agrárias, 32(9), 995-1004, https://doi.org/10.1590/S1415-43662013000900013

Siqueira, D. S., Marques Júnior, J., Pereira, G. T., Teixeira, D. B., Vasconcelos, V., Júnior O. C., \& Martins, E. D. S. (2015). Detailed mapping unit design based on soil-landscape relation and spatial variability of magnetic susceptibility and soil color. Catena, 135, 149-162, 


\section{Macrothink}

https://doi.org/10.1016/j.catena.2015.07.010

Soares, M. D. R., Campos, M. C. C., Oliveira, I. A., Cunha, J. M., Aquino, R. E., Silva, D. M. P., \& Souza, Z. M. (2018). Variabilidade espacial dos atributos do solo sob agrofloresta na região de Humaitá, AM. Gaia Scientia, 12(1), 33-41, http://doi.org/10.22478/ufpb.1981-1268.2018v12n1.34353

Souza, J. F. D., Perusso, R. L. S., Bonini, C. S. B., Souza, C. T., Lupatini, G. C., Andrighetto, C., \& Pedro, F. G. (2019). Atributos físicos, matéria orgânica do solo e produção de capim marandu em sistema de integração lavoura-pecuária-floresta. Revista Brasileira de Engenharia de Biossistemas, 13(1), 51-64, http://dx.doi.org/10.18011/bioeng2019v13n1p51-64

Uchôa, C. N., Pozza, E. A., Pozza, A. A. A., \& Moraes, W. S. (2011). Modelagem geoestatística da sigatoka-negra e sua relação com fertilidade do solo. Bioscience Journal, 27(3), 357-362.

Vieira, S. R. Geoestatística em estudos de variabilidade espacial do solo. In: Novais, R.F., Alvarez V., V. H. Schaefer, C. E. G. R. (2000). Tópicos em ciência do solo. Viçosa, MG, Sociedade Brasileira de Ciência do Solo.

Warrick, A. W., \& Nielsen, D. R. (1980). Spatial variability of soil physical properties in the field. In: HILLEL, D. (Ed.). Applications of soil physics. New York: Academic Press. cap. 2, p. 319-344.

Yeomans, J. C., \& Bremner, J. M. A. Rapid and precise method for routine determination of organic carbon in soil. Communication in Soil Science and Plant Analysis, 19(13), 1467-1476 https://doi.org/10.1080/00103628809368027

\section{Copyright Disclaimer}

Copyright for this article is retained by the author(s), with first publication rights granted to the journal.

This is an open-access article distributed under the terms and conditions of the Creative Commons Attribution license (http://creativecommons.org/licenses/by/4.0/). 